\title{
Spontaneous Intestinal Perforation in Neonate
}

\author{
Ade Nofendra ${ }^{1}$, Eny Yantri, Anggia Perdana Harmen
}

\begin{abstract}
Abstrak
Spontaneous Intestinal Perforation (SIP) terjadi pada 8,4 persen bayi dengan berat badan lahir sangat rendah. SIP ditandai dengan onset mendadak dan tidak ditemukannya tanda infeksi. Presentasi klinis SIP pada bayi bervariasi, dan etiologinya belum diketahui secara pasti. Konsekuensi klinis SIP dapat menimbulkan komplikasi yang cukup parah sehingga dokter harus menyadari kemungkinan penyebab dan gejala. Terapi utama SIP yaitu: drainase peritoneum dan laparotomi dengan reseksi. Dilaporkan kasus SIP pada by perempuan usia 2 hari, yang didiagnosis berdasarkan gejala klinis dan rontgen abdomen. Pasien dilakukan pemasangan drainase di abdomen dan mengamai perbaikan klinis.
\end{abstract}

Kata kunci: spontaneous intestinal perforation, bayi baru lahir, prematur

\begin{abstract}
Spontaneous Intestinal Perforation (SIP) have been documented to occur in as many as 8.4 percent of Very Low Birth Weight (VLBW) newborns. SIP can be characterized by a sudden onset and a lack of infectious. However, the presentation in infants affected SIP varies and the etiology is yet to be definitively determined. Yet the consequences of intestinal perforation are potentially severe enough that clinicians should be aware of the possible causes and symptoms. Two main treatments exist for intestinal perforation: peritoneal drainage and laparotomy with resection. We are presenting a case of 2 days old female newborn with SIP, diagnosed by clinical manifestation, abdominal $x$ ray. Patient underwent abdominal drainage and got clinical improvement.
\end{abstract}

Keywords: spontaneous intestinal perforation, neonate, premature

Affiliasi penulis: Bagian IImu Kesehatan Anak Fakultas Kedokteran Universitas Andalas/RSUP M Djamil Padang

Korespondensi: Ade Nofendra

Email:ade_nofendra@yahoo.co.idTelp: 085263181987

\section{INTRODUCTION}

Spontaneous Intestinal Perforation (SIP) have been documented to occur in as many as 8.4 percent of very low birth weight (VLBW) newborns. ${ }^{1}$ Gastrointestinal (GI) perforations first appeared in the literature in 1825 when siebold described a gastric perforation in an estimated 34 week gestational age infant. $^{2}$ Thelander in 1939 described the first cases of spontaneous perforation in three stillborn infants as perforations proximal to the ileocecal valve. ${ }^{3}$

It was not until the late 1980s that a specific subset of these perforations was defined as SIP.
Aschner et al and Zamir et al were among the first to claim that SIP is an entity with manifestations and outcomes different from those of necrotizing enterocolitis (NEC). ${ }^{4,5}$ SIP appears to be occurring with increasing frequency as a disease process distinct from NEC. This is perhaps a result of the increasing rate of survival of the VLBW infant,in whom SIP more frequently occurs. ${ }^{6}$

SIP can be characterized by a sudden onset and a lack of infectious. However, the presentation in infants affected SIP varies, and the etiology is yet to be definitively determined. The clinical stability and initial lack of symptoms associated with SIP can make early diagnosis diffcult. Yet the consequences of intestinal perforation are potentially severe enough that clinicians should be aware of the possible causes and symptoms. ${ }^{7}$ 


\section{CASE}

Reported an 4 hours old female newborn, hospitalized at M Djamil Hospital since November $26^{\text {th }}$ 2018, referred from Andalas University Hospital with chief complain is Grunting since birth. Low birth weight of neonate 2200 grams, length $44 \mathrm{~cm}$, sectio cesarean delivery due to mother with severe pre eclampsia, preterm 35-36 weeks,APGAR Score 5/7, no data about mother white blood count, amniotic fluid was clear. Grunting since birth, breathlessness was present, cyanotic was lost by giving oxygen. There was no fever, seizure, and vomiting. Vitamin $\mathrm{K}$ had been given after delivery. Mother has no history of fever, vaginal discharge, and pain when micturition during pregnancy or before delivery. Mother only used prescribed medicine by midwife or doctor. She received routine antenatal care from midwife. Previously, patient had been hospitalized for 2 hours at Anadalas University Hospital, treated with loading $\mathrm{Na} \mathrm{Cl} 0.9 \% 22 \mathrm{cc} /$ half hours, ampicilin sulbactame $2 \times 110 \mathrm{mg}$ iv, gentamicin $1 \times 10 \mathrm{mg}$; had been performed laboratory examination with result : $\mathrm{Hb} 15$ $\mathrm{g} / \mathrm{dl}$, white blood cells $10.0000 \mathrm{~mm}^{3}$, platelets $213.000 / \mathrm{mm}^{3}$. The child than was referred to M.Djamil central hospital with note respiratory distress due to transient takipnue of newborn, hemodinamic distubance, history of hipotermia.

On Physical examination the child was alert, less active. Heart rate at $130 \mathrm{bpm}$ regular, respiratory rate at $72 \mathrm{rpm}$, and body temperature at $36,8^{\circ} \mathrm{C}$, body weight 2200 gram. No edema, cyanotic and pale. The conjunctiva was not anemic, sclera was not icteric. Isochor pupil with diameter of $2 \mathrm{~mm}$, light reflex $+/+$ normal. Nasal flare was present. Chest symmetrical shape, retraction on epigastrial and intercostal regions, and no wheezing or rales. Regular heart rhythm, no murmur. Abdominal was supple, liver palpable 1/4 1/4, flat surfaces, sharp edge, chewy consistency. Spleen was not palpable. Percussion tympani, bowel sound (+) normal. Puberty state was A1G1P1. Peripherally acral was warm, and good capillary refilling time.

Down Score: retraction on epigastrium 1, grunting 1 , cyanotic 1 , air entry 1 , respiratory rate 1 , total 5. Impression: Moderate respiratory distress. Routine laboratory examination result; hemoglobin 15 $\mathrm{gr} / \mathrm{dl}$, white blood cell $10.000 / \mathrm{mm}^{3}$, platelet 213.000/mm ${ }^{3}$, differential count 0/1/2/52/31/14 .

Patient diagnosed as respiratory distress due to Transient Takipnue of Newborn (TTN) Low birth weight of newborn 2200 gram. Treatment on this patient NCPAP PEEP 7 FiO2 30\%, IVFD PG1 60 $\mathrm{cc} / \mathrm{kgbb} /$ day, 5,5 cc/hour, ampicilline sulbactame $2 \mathrm{x}$ $110 \mathrm{mg}$ iv, gentamicin $1 \times 10 \mathrm{mg}$ iv.

On November 26th, 2018 patient still used CPAP, breathlessness was present, no desaturation, no fever. Patient still fasting. Patient looked less active, blood pressure $64 / 41 \mathrm{mmHg}$, heart rate 136 times/minute, respiratory rate 54 times/minute, temperature $36.5^{\circ} \mathrm{C}$, conjuctiva was not anemic, sclera was not icteric. Normochest, retraction in epigastrial region, heart sound: regular rhythm, no murmur, lung: broncovesicular, no rales and no wheezing. There was no abdominal distension, liver was palpable $1 / 4-1 / 4$, and peristaltic sound was normal, extremities were warm with good perfusion. Impression: Respiratory distress due to TTN. Treatment: CPAP PEEP $7 \mathrm{FiO}_{2}$ 30\%, IVFD D PG1 5.5 cc/hour, ampicillin sulbactame 2 $x 110 \mathrm{mg}$ iv and gentamicin $1 \times 10 \mathrm{mg}$ iv.

On the second day follow up at $7 \mathrm{AM}$, patient still used CPAP, breathlessness was present, decreased than before, no desaturation, no fever. There was distention on abdominal, no hiperemic on abdominal. Patient still fasting. Patient looked less active, blood pressure $66 / 44 \mathrm{mmHg}$, heart rate 150 times/minute, respiratory rate 50 times/minute, temperature $36.5^{\circ} \mathrm{C}$, conjuctiva was not anemic, sclera was not icteric. Normochest, retraction in epigastrial region, heart sound: regular rhythm, no murmur, lung: broncovesicular, no rales and no wheezing. There was abdominal distension, liver was palpable $1 / 4-1 / 4$, and peristaltic sound was normal, extremities were warm with good perfusion. Impression: Respiratory distress due to TTN and suspect intestinal perforation. Treatment: CPAP PEEP $6 \mathrm{FiO}_{2}$ 21\%, IVFD D PG1 5.5 cc/hour, ampicillin sulbactame $2 \times 110 \mathrm{mg}$ iv and gentamicin $1 \times 10 \mathrm{mg}$ iv. Planning: abdominal $X$ ray 


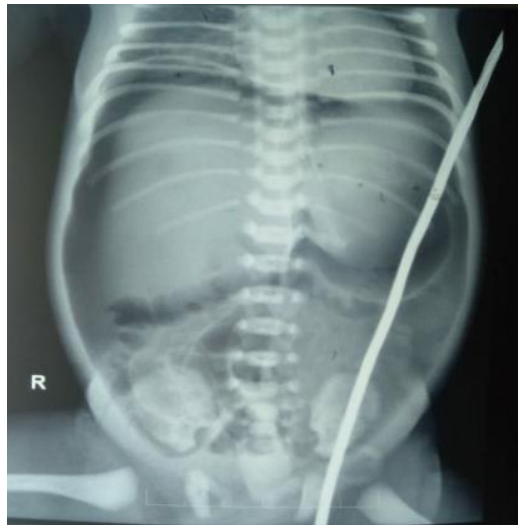

Figure 1. Abdominal X Ray

Expertise of abdominal $X$ ray: There was no picture of pre peritoneal fat. There was pneumoperitoneum. There was no intestinal dilatation. Impression: Pneumoperitoium due to??

On the second day follow up at 05.00 PM, patient still used CPAP, breathlessness was present, decreased than before, no desaturation, no fever. There was distention on abdominal, no hiperemic on abdominal. Patient still fasting. Patient was planned for peritoneal drainage. Patient looked less active, blood pressure $59 / 43 \mathrm{mmHg}$, heart rate 140 times/minute, respiratory rate 50 times/minute, temperature $36.8^{\circ} \mathrm{C}$, conjuctiva was not anemic, sclera was not icteric. Normochest, retraction in epigastrial region, heart sound: regular rhythm, no murmur, lung: broncovesicular, no rales and no wheezing. There was abdominal distension, liver was palpable $1 / 4-1 / 4$, and peristaltic sound was normal, extremities were warm with good perfusion. Impression: Respiratory distress due to TTN and spontaneous intestinal perforation. Treatment: CPAP PEEP $6 \mathrm{FiO}_{2} 21 \%$, IVFD D PG1 7.3 cc/hour, ampicillin sulbactame $2 \times 110 \mathrm{mg}$ iv and gentamicin $1 \times 10 \mathrm{mg}$ iv, peritoneal drainage

On the third until sixth day follow up, patient still used CPAP, breathlessness was not present, no desaturation, no fever. Patient has been done peritoneal drainage, there was no distention on abdominal. Patient still fasting. Patient looked less active, blood pressure $63 / 46 \mathrm{mmHg}$, heart rate 130 times/minute, respiratory rate 44 times/minute, temperature $36.8^{\circ} \mathrm{C}$, conjuctiva was not anemic, sclera was not icteric. Normochest, retraction in epigastrial region, heart sound: regular rhythm, no murmur, lung: broncovesicular, no rales and no wheezing. There was abdominal distension, liver was palpable $1 / 4-1 / 4$, and peristaltic sound was normal, extremities were warm with good perfusion. Impression: Respiratory distress due to TTN and spontaneous intestinal perforation. Treatment: Weaning CPAP, IVFD IVFD D 12,5\% 7.9 $\mathrm{cc} /$ hour, aminofusine infant $6 \% 5.3 \mathrm{cc} / \mathrm{jam}$, smoof lipid $0.4 \mathrm{cc} / \mathrm{jam}$, ampicillin sulbactame $2 \times 110 \mathrm{mg}$ iv and gentamicin 1 x $10 \mathrm{mg}$ iv. Planning : Abdominal $X$ ray

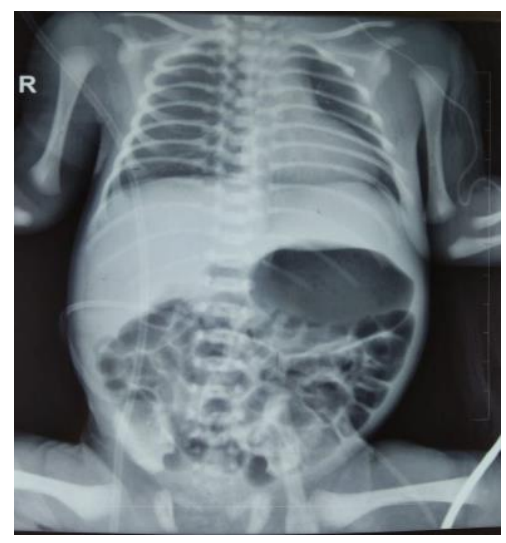

Figure 2. Abdominal $X$ ray

On seventh until tenth day follow up, patient was not breathlessness, no desaturation, no fever. There was no distention on abdominal. Patient started to feed. Patient looked active, blood pressure 66/45 $\mathrm{mmHg}$, heart rate 120 times/minute, respiratory rate 48 times/minute, temperature $37^{\circ} \mathrm{C}$, conjuctiva was not anemic, sclera was not icteric. Normochest, retraction in epigastrial region, heart sound: regular rhythm, no murmur, lung: broncovesicular, no rales and no wheezing. There was no abdominal distension, liver was palpable $1 / 4-1 / 4$, and peristaltic sound was normal, extremities were warm with good perfusion, icteric cramer grade 4-5. Impression: Respiratory distress due to TTN and spontaneous intestinal perforation. Treatment: IVFD D 12,5\% $7.9 \mathrm{cc} /$ hour, aminofusin infant $6 \% 5.3 \mathrm{cc} / \mathrm{jam}$, smoof lipid $0.4 \mathrm{cc} / \mathrm{jam}$, breast feed $12 \times 3 \mathrm{cc}$, ampicillin sulbactame $2 \times 110 \mathrm{mg}$ iv and gentamicin 1 x $10 \mathrm{mg}$ iv. Stop antibiotic.

On eleventh until fourteenth day follow up,patient was not breathlessness, no desaturation, no fever. There was no distention on abdominal. Tolerance to drink was good, patient breastfeed on demand. Patient looked active, blood pressure 68/47 $\mathrm{mmHg}$, heart rate 140 times/minute, respiratory rate 48 times/minute, temperature $37^{\circ} \mathrm{C}$, conjuctiva was not 
anemic, sclera was not icteric. Normochest, retraction in epigastrial region, heart sound: regular rhythm, no murmur, lung: broncovesicular, no rales and no wheezing. There was no abdominal distension, liver was palpable $1 / 4-1 / 4$, and peristaltic sound was normal, extremities were warm with good perfusion. Impression: Improvement . Treatment: breastfeed on demand. Planning : patient was discharged.

\section{DISCUSSION}

Patient diagnosed as Spontaneous Intestinal Perforation (SIP). Diagnosis SIP was made based on history of distention on abdominal, patient still fasting, and we found pneumoperitonium in abdominal $X$ ray. SIP is an acquired neonatal intestinal disease and it is defined as a single or, less frequently, multiple perforation, typically in the terminal ileum, without evident cause,as in the present case. SIP presents earlier in life, at a mean age of 7 days (vs 15 days for NEC), often with a typical black-bluish discoloration of the abdomen. ${ }^{8}$ SIP is the second most common cause of neonatal intestinal perforation and has been very well documented in the low-birth-weight neonates. Its incidence is $1.1 \%$ in VLBW \& $7.4 \%$ in ELBW neonates. Only a few cases have been described in full-term neonates. $^{9}$

SIP occurs in infants of very low birth weight $(2 \%-3 \%<1500 \mathrm{~g})$ and extremely low birth weight $(5 \%$ $<1000 \mathrm{~g}$ ). The median gestational age range is 25 to 27 weeks, and the median birth weight range is 670 to $973 \mathrm{~g}$. Severe placental chorioamnionitis is an antenatal risk factor for SIP. Antenatal exposure to indomethacin has not been found to be associated with SIP at this point, but those infants exposed to it during the first few days after birth (within close proximity to antenatal corticosteroids) are at increased risk of SIP. Some studies have found that it occurs more frequently in male compared with female infants. ${ }^{10}$

Etiology of SIP is still not known. Important role in intestinal damage is related to focal ischemia, motility impairment and hypoplasia of intestine muscle layer observed in the histological assessment. Risk factors are the following: prematurity, low body weight, male sex, multiple pregnancy, respiratory distress. ${ }^{11}$ These factors along with the organ immaturity of the neonate can lead to the focal ischemia of the intestinal wall. Umbilical vessels catheterization and therapy with Indomethacine used in profylaxis of haemorrhage to the central nervous system or as a treatment of persistent ductus arteriosus can be the reasons, among other, of intestinal ischemia. ${ }^{9}$

Mechanical ventilation with nasal prongs or face mask has also been identifed as a risk factor for SIP. The distending pressure transmitted to the intestines could lead to perforation. In a 1985 study, Garland et al reviewed the cases of 15 infants who were ventilated with either face mask or prongs and developed a Gl perforation not related to NEC. In this matched case control study, infants ventilated with either mask or prongs were found to be 30 times more likely to experience both upper and lower Gl perforations than were infants ventilated with endotracheal tubes. Risk factors for patient were low birth weight and used CPAP. ${ }^{12}$

The onset of SIP is often insidious, and the patient is clinically stable. Aschner et al reviewed the cases of six LBW neonates with SIP. When compared with neonates with NEC,who generally present with signifcant clinical deterioration, the six infants in this review were remarkably stable. The consistent finding in the review was a blue-black discoloration of the abdominal wall. The reviewers proposed that this discoloration occurs secondary to staining of the underlying tissues by meconium in the peritoneal fluid. The staining is easy to see in premature infants because they lack subcutaneous tissue. This blueblack discoloration of the abdomen has been noted by other investigators. ${ }^{4}$ This finding was also the most consistent symptom reported by the authors of the studies reviewed for this manuscript. ${ }^{13}$ In several of the cases documented by Aschner et al, SIP was not associated with peritonitis, and only one of six infants had positive peritoneal cultures. Additional signs and symptoms of SIP include abdominal distention, delayed first stool after the third postnatal day, and leukocytosis. Many infants, however, present with no symptoms at all. ${ }^{4}$

In radiological images the most common is the presence of free air in abdominal cavity (pneumoperitoneum) and rarely airless abdomen. The lack of intestinal pneumatosis characteristic for 
necrotizing enterocolitis is an important fnding in differential diagnosis. In this patient, founded pneumoperitonium and didnt found pneumatosis. ${ }^{14}$

Laboratory tests usually reveal increased levels of inflammatory markers but they do not allow to differentiate SIP with other abdominal pathologies. The importance of cytokines (IL-8, IL-10) and I-FABP (Intestinal Fatty Acid Binding Protein) levels characteristic for the early stage of intestine damage in NEC. Bacterial cultures of peritoneal fluid in SIP reveal most often the presence of Staphylococcus sp. ${ }^{15}$

Recognition of SIP is the indication for surgical treatment. Single or rarely multiple perforations 2-12 $\mathrm{mm}$ in diameter localized on the antimesentery adge of the terminal part of ileum are seen intraoperatively. The remaining segments of intestine are macroscopically unchanged. Surgical strategy in SIP is determined by general condition of the neonate. In the most severe cases the peritoneal drainage is used enabling for stabilization of the neonate condition and delayed laparotomy performance. In selected cases peritoneal drainage can be fnal and effective treatment option for patients with SIP. It is estimated that up to $70 \%$ of patients treatmented with drainage, the delayed needed laparotomy. ${ }^{14}$

The most common procedure performed in neonates with SIP is two-stages operation. The first stage includes resection of the intestine with perforation with ileostomy performance. Haemodynamic instability during operation is the indication for temporary exposure of the intestine with perforations into the skin. The continuity of the digestive system was restored 3-6 months later which depended on patient' general condition and his/her "tolerance" of intestine enterostomy. Final diagnosis of spontaneous intestinal perforation is confrmed by histological assessment. Lymphocyte infltrations, haemorrhagic necrosis, muscle layer defect and multipole thinwalled vessels close to the perforation are characteristic fndings in microscopic evaluation. ${ }^{16}$

The relevant factor for prognosis in SIP is frequent occurrence of other diseases in neonates with low birth body weight. The most important are concomitant neurological disturbances (intracranial haemmorhages, leucomalation), respiratory distress (broncho-pulmonary dysplasia) and cardiologic disorders (congenital heart diseases). Taking into account above factors the outcome of surgical treatment of the patients with SIP is good. Survival rate ranges from 70 to $100 \%$ depending on the patient' health condition and concomitant pathologies and is higher in patients with NEC treated surgically. ${ }^{17}$

\section{CONCLUSION}

The incidence of SIP is increasing as more VLBW infants are surviving and since SIP has been identifed as a separate disease from Necrotizing Enterocolitis (NEC). SIP potential to increase morbidity and mortality in premature infants warrants further research to improve outcomes

\section{REFERENCES}

1. Attridge J, Herman A, Gurka M, Griffn M, Gordon $P$. Discharge outcomes of extremely low birth weight infants with spontaneous intestinal perforations. J Perinatol. 2006;26:49-54.

2. Ahmad I, Davis KF, Emil S, Uy C, Sills J. Risk factors for spontaneous intestinal perforation in extremely low birth weight infants. Perinatology. 2008;10:125-30.

3. Gordon PV, Attridge JT. Understanding clinical literature relevant to spontaneous intestinal perforations. Am J Perinatol. 2009;26:309-16.

4. Aschner JL, Deluga KS, Metlay L, Emmens RW, Hendricks MK. Spontaneous focal gastro intestinal perforation in very low birth weight infants. The Journal of Pediatrics.1998;113: 364367.

5. Zamir O, Goldberg M, Udassin R, Pele O, Nissan S, Eyal F. Idiopathic gastrointestinal perforation in the neonate. J Pediatr Surg.1988;23:335-7.

6. Resch B, Mayr J, Kuttnig-Haim M, Reiterer F, Ritschl E MW. Spontaneous gastrointestinal perforation in verylow-birth-weight infants-a rare complication in a neonatal intensive care unit. Pediatr Surg Int. 1998;13:165-7.

7. Komura H, Urita Y, Hori T, Hira M, Kudou S, Gotoh C. Perforation of the colon in neonates. J Pediatr Surg. 2005;40:1916-9.

8. De Abreu Amaro C, Oliveira Pereira C, Mesquita J. Spontaneous intestinal perforation in a preterm neonate. BMJ Case Rep. 2018;11:e226565. 
9. Tiwari C, Sandlas G, Jayaswal S, Shah $H$. Spontaneous intestinal perforation in neonates. J Neonatal Surg. 2015;4: 2-5.

10. Sims ME. Legal Briefs: failure to diagnose spontaneous intestinal perforation. Neoreviews. 2014;15: 498-501.

11. Stringer MD. Spontaneous intestinal perforation. Newborn Surgery. Fourth Ed. 2017.hIm.660-6.

12. Garland J, Nelson D, Rice T, Neu J. Increased risk of gastrointestinal perforations in neonates mechanically ventilated with either face mask or nasal prongs. Pediatrics. 1985;76:706-10.

13. Attridge JT, Clark R, Walker MW, Gordon P V. New insights into spontaneous intestinal perforation using a national data set: (1) SIP is associated with early indomethacin exposure. J Perinatol. 2006;26:93-9.
14. Holland AJA, Shun A, Martin HCO, CookeYarborough C, Holland J. Small bowel perforation in the premature neonate: Congenital or acquired? Pediatr Surg Int. 2003;19:489-94.

15. Guthmann F, Börchers T, Wolfrum C. Plasma concentration of intestinal and liver-FABP in neonates suffering from necrotizing enterocolitis and in healthy preterm neonates. Mol Cell Biochem. 2002;239:227-34.

16. Rattan KN, Yadav A, Dalal P, Singh J. One-time needle aspiration: a safe and effective treatment for neonatal spontaneous pneumoperitoneum. 2018;7:1-6.

17. Shah J, Singhal N, Da Silva O, Rouvinez-Bouali N, Seshia M, Lee SK, et al. Intestinal perforation in very preterm neonates: Risk factors and outcomes. J Perinatol. 2015;35:595-600. 